\title{
Bronchocentric granulomatosis: Clinical course illustrated by serial computerized tomography of the chest
}

\author{
JOHN T GRANTON MD FRCPC, DEAN W CHAMBERLAIN MD FRCPC, ROBERT H HYLAND MD FRCPC \\ Departments of Medicine and Pathology. The Wellesley Hospital and \\ The Toronto Hospital, University of Toronto, Toronto, Ontario
}

JT Granton, DW Chamberlain, RH Hyland. Bronchocentric granulomatosis: Clinical course illustrated by serial computerized tomography of the chest. Can Respir J 1994;1(4):261-264.

Bronchocentric granulomatosis is a pathological process characterized by granulomatous inflammation in conducting airways. A case of bronchocentric granulomatosis of unknown etiology in a previously well 24-year-old female is reported. The variable and often fluctuating course of this entity and its response to corticosteroids is demonstrated by serial computerized tomography of the chest. The pathology, etiology and therapy of bronchocentric granulomatosis is reviewed.

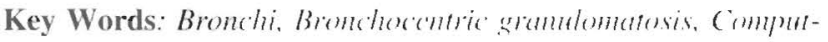
erized tomograph: Idionuthic.
Granulomatose bronchocentrique: Évolution clinique illustrée par tomodensitométrie thoracique en série

RÉSUMÉ : La granulomatose bronchocentrique est un processus pathologique caractérisé par une inflammation granulomateuse des conduits aériens. Un cas de granulomatose bronchocentrique d'étiologie inconnue chez une femme de 24 ans auparavant en bonne santé est signalé. L'évolution de cette malidie souvent variable et incertaine. et sa réponse aux corticostéroüdes, est démontrée par tomodensitométrie thoraciyuc en série. La pathologic, l'étiologie et le llaitement de la granulomatose bronchocentrique sont examinés.
$\mathrm{B}$ RONCHOCENTRIC GRANULOMATOSIS (BCG) REPRESENTS a nonspecific response to various forms of airwaly injury $(1,2)$. It is important to exclude an infectious cause in all patients and fungal colonization in asthmatic pa- tients. The radiographic appciarance of BCG is diverse and no pattern appears to hc pathognomonic. Features on plain chest radiographs do not consistently correlate with disease presentation (3). To our knowledge the appearance of BCG on 
computerized tomography (CT) of the chest has not been described.

We report a patient with $\mathrm{BCG}$ for which no catuse could be identified. CT of the chest was used to follow her elinical course and guide therapentic decisions.

As the result of our experience with this patient we believe that CT maly be at useful tool to follow the course of this pathological process.

\section{CASE REPORT}

A 24-year-old female was reforred for assessment of fluctuating fatigne, low grade fever, anorexia and nonproductive cough associated with flecting alveolar opacities over the previous six months. There wats no history of hemoptysis. She was traated intermittently with oral antibiotics for presumed infection without obvious benefit. She was previously well and had no personal or family history of asthma. She had no exposure to animats or occupational agents. She was a nonsmoker and had no human immunodeficiency virus risk facters. Apart from intermittent use of antibiotics over the previous months, she was taking no medication at the eime of assessment. Her physical examination was normal. Her white blood cell count was clevated $(17.0 \times 10 \% / \mathrm{L})$ with a prominent neutrophilia $\left(13.6 \times 10^{6} / \mathrm{L}\right)$ without cosinophilia and her hemoglobin wals $95 \mathrm{~g} / \mathrm{L}$ with nomal red hlood cell indices. The sedimentation rate was elevated to $43 \mathrm{~mm} / \mathrm{h}$. Urinalysis was normat. Chest radiograph revealed bilateral, patehy, basilar airspace disease (Figure 1). There was no evidence of airflow obstruction, and her diflusing capacily, corrected for hemoglobin, was normal. A CT scan of the chest demonstrated impressive basilar nodules some of which had cavitated (Figure 1). Bronchoscopy with transhronchial biopsy and bronchoalveolar lavage were noncontributory including cultures for lungi and bacterial. Open lung biopsy showed airway centred ulcerative disease associated with aleute neulophil-dominant inflammation admixed with a definitc granulomatous component (Figure 2). There wats nocvidence of a primary vasculitis. Eosinophils were present but did not predominate. Periodic-acid Schiff, /ichl-Neelson and silver methenamine statms as well as culture of tissue did not reveal any pathogens. These features were indicative of BCG. A scarch for an etiology was unrewarding. The patient hat no history of asthmal and serum immunoglobulin Eand aspergillus precipitins were not elevated. Rheumatoid factor, antinuclear antibodics, complement studics and antineutrophil cytoplasmic antibodies (ANCA) were negative.

During convalescence from surgery all of her symptoms improved without specilic therapy. A follow-up CT scan one month later demonstrated that the parenchymal opacities were resolving and no areas of calvitation could be identified (Figure 3). Five months later she complaned of right-sided pleuritic chest pain in the regiont of her surgery. A chest radiograph performed at this time appeared unchanged from her postoperative examinations. $\triangle$ limited high resolution $C T$ examination through the region of her pain was performed. Owing to a change in scan technique $(1.5 \mathrm{~mm}$ versus $10 \mathrm{~mm}$ collimation) and patient positioning, subsequent CT scan
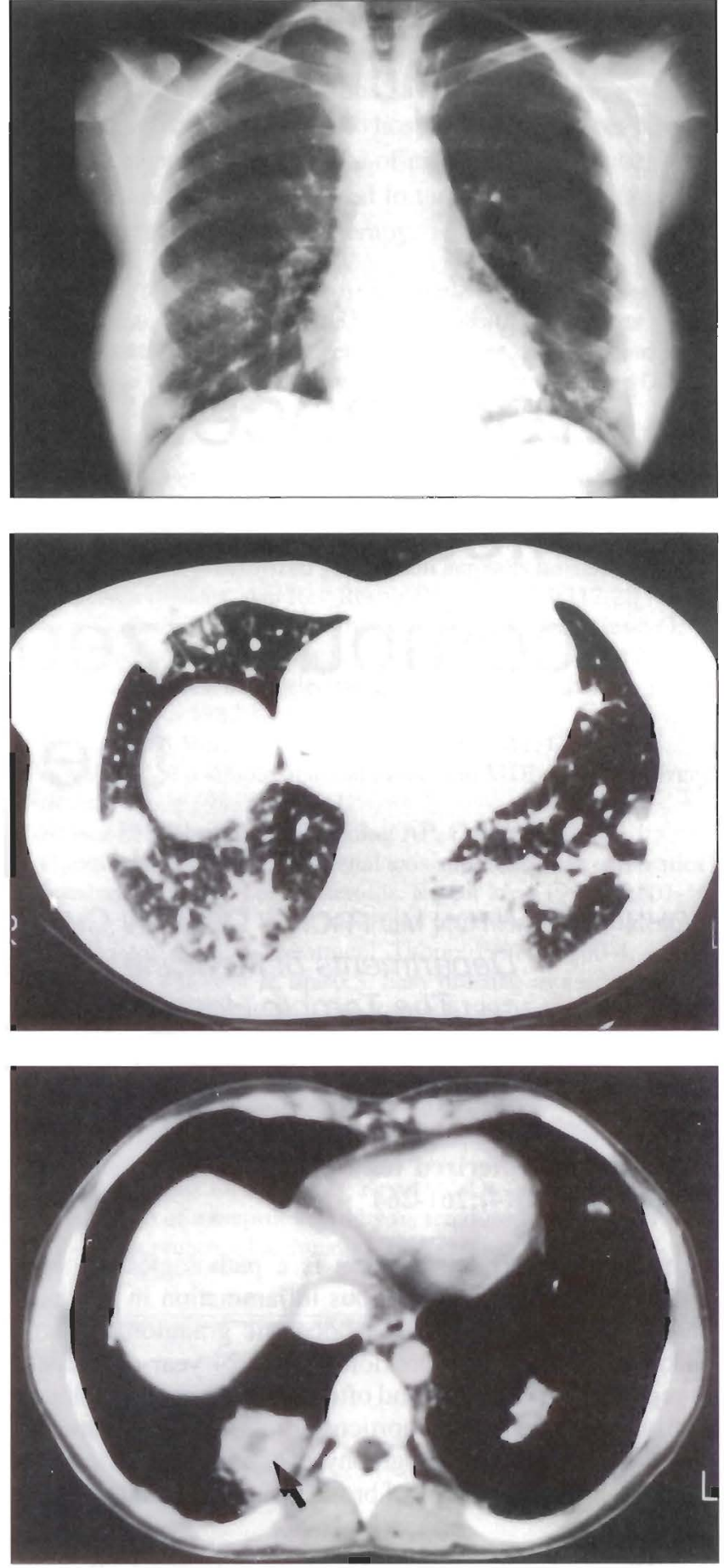

Figure 1) (Top) Roentgenogram demonstrating patchy bibasilar airspace disease. A computritsd lommeraphic scan using $10 \mathrm{~mm}$ collimation revealed large nodule's scultered throughou both hungs (middle), some of which had cavituted (bottom) (arrow)

levels were not identical to those obtatined previously. However, a section obtaned all approximately the same level as the initial stady (Figure 3) and accompanying culs did demonstrate recurrence of the lung nodules. Therapy consisting of daily prednisone 40 mg oratly was initiated.

Her symptoms subsequently improved over two weeks. Prednisone was decreased slowly over one-atnd-a-hall months 


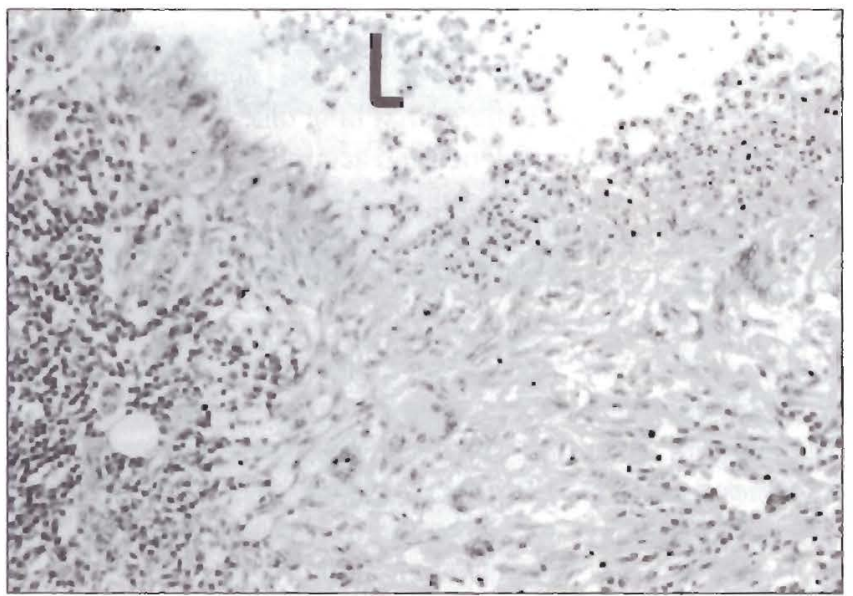

Figure 2) Pholomicrograph showing an inflames hronchial wall.

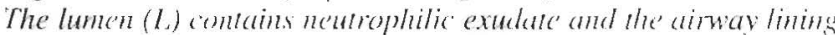

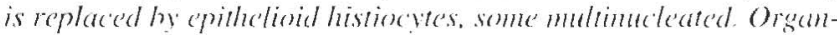
ism stains nere negative (hamatorylin and eosin $\times 78$ )

to $15 \mathrm{mg} / \mathrm{day}$ and she remained asymptomatic. A subsequent limited high resolution $\mathrm{CT}$ scan through her chest showed that the parenchymal opacities had again decreased in size (Figure 3). Over the ensuing 18 months, attempts to taper steroids further were met with a relurn of symptoms and densities on limited CT scanning. Routine chest radiography failed to demonstrate new parenchymal abnormalities during flares in her illness. At this time, three years after her initial presentation, we have successfully discontinued her prednisone. Her latest limited CT scan was free from nodular disease

\section{DISCUSSION}

Liebow (4) characterized BCG as a necrotizing granulomatous inflammation centred on peripheral airways. He included BCG with the classification of four forms of angiitis: classical Wegener's granulomatosis; limited Wegener's; lymphomatoid granulomatosis; and necrotizing sarcoid granulomatosis. However, BCG differs lrom these other diseases as it is not primarily angiocentric and does not involve extrapulmonary sites. Katzenstein and colleagues (5) reviewed $B C G$ and identified two groups of pattients based on clinical and pathological findings in 23 paticnts. The first comprised asthmatics in whom peripheral eosinophilia and a sensitivity to aspergillus were observed. On examination of lung sections the lesions exhibited tissue cosinophilial in addition to granulomatous inflammation. Scattered fungal hy phac could often be seen in the intraluminal exudate. In this group of patients BCG appears to represent a form of allergic bronchopumonary aspergillosis and to be in inflammatory response to inhialed antigen (5). The second and larger group comprised nonasthmatic paticnts.

Eosinophilia was absent and the airway-centred infiltrates were predoninantly neutrophilic. Proximal obstruction with sustained inflammation and distention of distal airways was commonly obscrved, and this pathological appearance has been postulated to be at requirement for the development of BCG (1). In this regard, BCG likely represents the lung's
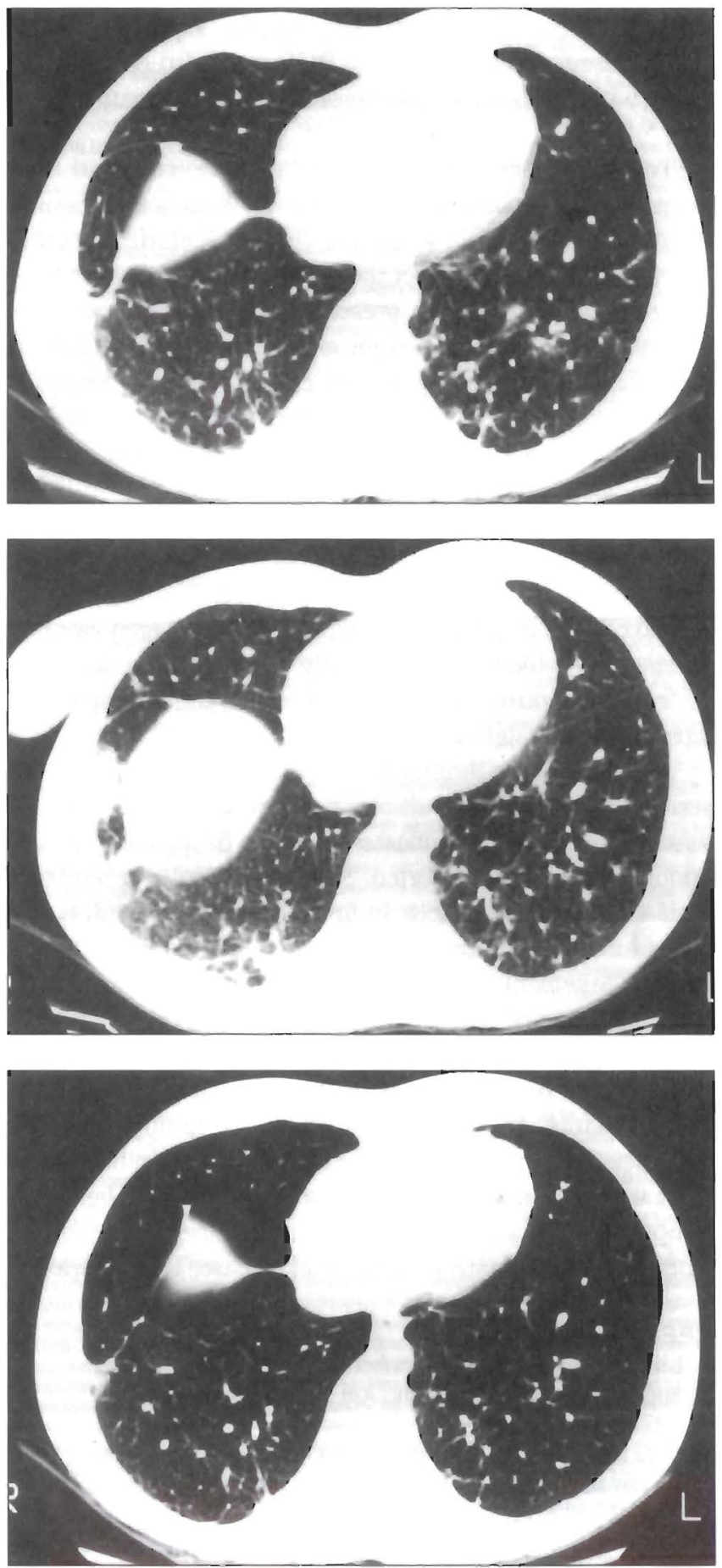

Figure 3) High resolution ( $1.5 \mathrm{~mm}$ collimation) $\mathrm{CT}$ secans of the chest. One month after an onen lung biopsy improveme'nt in the' lang nodules was seen (top). Five months later a repeat limited $\mathrm{Cl}$ (middle) show'ed that the nodule's had returned. During theraps with prednissne the nodules aseain disedpecared (bottom)

limited inflammatory response to at wide variety of injurious agents. As emphasized by Myers and Katzenstein (6), in this group of patients infectious causes need to be calrefully excluded by appropriate cultures and tissue stains. In one study of solitary necrotizing granulomas of the lung, $27 \%$ of patients with tuberculosis had bronchocentric granulomas identified (7). In addition to tuberculosis. BCG has been 
reported in paticnts with histoplasmosis. aspergillosis and echinococcus infection (6,8,9). BCG may also occur in pattients with seropositive and seronegative arthropathies (10)12).

To add to the dilliculty. BCG may be conlused with Wegener's granulomatosis. Reports of Wegener's gramulomatosis demonstrating a relative bronchocentric" distribution that predominated over the associated angitis have been described (13). Thus, the presence of primary vascular involvencent needs to be sought and the presence of ANCA excluded. Patients in whom no cause including inlection could be identilied have been reported and represented $25 \%$ of Kallenstien and co-worker"s pallicnt population.

Our patient hat no evidence of asthma or demonstrable sensitivity fo aspergillus. Despite appropriate staining and culturing of lung lissuc and bronchoalveolar lavage samples, no infectious etiology could be identified. Furthermore she had no clinical or serological evidence of a collagen vascular discalse nor evidence histologically to support the diagnosis of "broncherentric" Wegener"s. Thus our patient appears to have $\mathrm{BCG}$ of undetined etiology.

A variety of radiographic appearances have been described in BCG (3). Multiple, or more commonly solitary mass lesions, cavitating masses, alveolar filling and reticulonodular patterns are reported. Scattered nodules resembling metastasis have been secon in up to $35 \%$ ol cases (3.4). An upper lobe distribution appears to predominate. Hilar lynph node enlargement is infrequent. Hence, no radiographic pattern appears to be specific for any eliology. We are unaware of any description of the use of " T in diagnosing or following paticnts with BCG. In this patient, the initial CT appearance was dramatic and disproportionate to the radiographic appearance and her symploms. Subsequent flares in her illness were not accompaniod by any notable changes in her chest radiograph. CT scanning, however, was useful in demonstrating regions of new parenchymal disease. The superiority

\section{REFERENCES}

1. Liebow A. The J. Burns Amberson Lecture - Pulmonary angiitis and granulomatosis. Am Rev Respir Dis 1973;108:1-16.

2. (lee M, Lamb D, Clark R. Bronchocentric granulomatosis: A review and thoughts on pathogenesis. Br J Dis Chest [983;77:227-34.

3. Myers J. Bronchocentric granulomulosis: Disease or diagnosis? Chest 1989;96:3-4.

4. Robinson R, Wehunt W, Tsou E, Koss M, Hochhol/er I.. Bronchocentric granulomatosis: Roentgenographic manifestations. Am Rev Respir Dis 1982:125:75 I-().

5. Katzenstein A, Liebow A, Friedman P. Bronchocentric granulomatosis, mucoid impaction, and hypersensitivity reactions to fungi. Am Rev Respir Dis 1975;111:497-537.

6. Myers J, Katzenstein A. Granulomatosis infection mimiching bronchocentric granulomatosis. Am J Surg Pathol 1986;10:317-22.

7. Ulbright TM, Katzenstein A. Solitary necrotizing granulomas of the lung. Differentiating features and etiology. Am J Surg Pathol 1980;4:13-28.

8. Makker H, McConnochic K, Gibbs A. Postirradialtion of CT to plain radiography hats been described in a variefy of diffuse lung discases. Mathieson el al (14) demonstraled that, in the setting of diffuse interstitial lung disease, radiologists' level of diagnostic confidence and accuracy was significantly greater for CT compared with chest radiography. CT scanning may also aid in defining the course and prognosis of diffuse lung disease. In one study cxamining CT appearances before and after therapy in patients with sarcoidosis, groundglass, nodular, and interlobular septal thickening correlated with potentially reversible discilse, while cystic airspaces and architecturat distortion correlated with progressive or irreversible disease (15). In the present patient CT assisted in making therapeutic decisions and in following her response to therapy. Importantly, we were athle to reduce the amount of radiation exposure by limiting CT imaging 10 small regions of the chest and using $1.5 \mathrm{~mm}$ collimation scans as opposed to $10 \mathrm{~mm}$ collimation scans. In this regard CT scanning may be a more useful tool than chest radiography for assessing activity of this pathologic entity.

This patient also highlights the variable course and icsponse to treatment in patients with BCG ol unknown etionogy. These patients often have spontancous remissions lasting months to years, making assessments of responsic to therapy difficult. We are confident that the corticosteroids administered following her second flare were responsible for her clinical and radiographic improvement. We base this assumption on the observation that a relurn in her symptoms and parenchymal densitics paralleled atlempls to decreasc her dose of prednisone. In addition lo conticosteroids, cyclophosphamide, arathoprine and surgery (for single mass k'sions) have been reported as being sucecsiful in cases where infectious causes have been reliably excluded $(5,16)$. There are no prospective interventional studies for idiopathic BCG and therapeutic claims are limited locaric reports. We suggest that CT scanning may represent a uselul tool for the catre of patients with BCG.

pulmonary fihrosis complicated by aspergilloma and bronchocentric granulomatosis. Thorax 1989;44:676-7.

9. Tazelar H, Baird A, Mill M, Grimes M, Schulman I, Smith ( . Bronchocentric mycosis occurring in transplant recipients. Chest 1989;96:92-5.

10. Rohatgi P, Turrisi B. Bronchocentric granulomatosis and ankylosing spondylitis. Thorax 1984;39:317-8.

11. Bonafede R, Benatar S. Bronchocentric gramulomatosis at)d rheumatoid arthritis. Br J Dis Chest 1987: $81: 197-201$.

12. Berendesen H, Hofstee N, Kapsenberg P. Siewertsz-van Reesema D, Kein J. Bronchocentric granulomatosis associated with seropositive polyarthritis. Thorax 1985;40:396-7.

13. Yousem S. Bronchocentric injury in Wegener's granulomatosis: A report of 5 cases. Hum Palhol (9) I:22:535-40.

14. Mathieson J, Mayo I, Staples C, Müller N. Chronic dilfuse infiltrative lung disease: Comparison of diagnostic accuracy of CT and chest rildiography. Radiology 1989:171:111-6.

15. Murdoch J, Muiller N. Pulnmmary sarcoidosis: Changes on follow-up CT examination. Am J Radiol 1992;159:473-7.

16. Saldana M. Bronchocentric granulomaltosis: Clinicopathologic observations in 17 pationts. Lah Invest 1979:40:281-2. (Abst) 


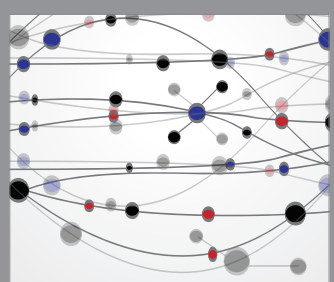

The Scientific World Journal
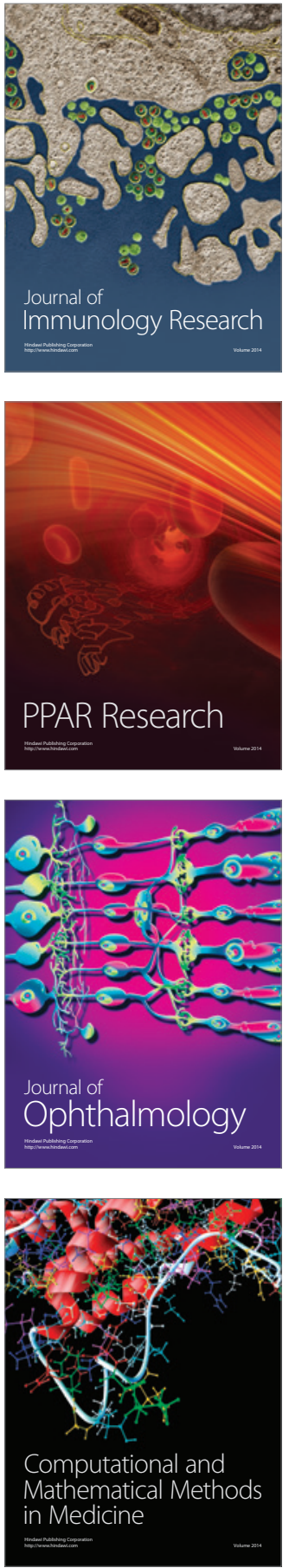

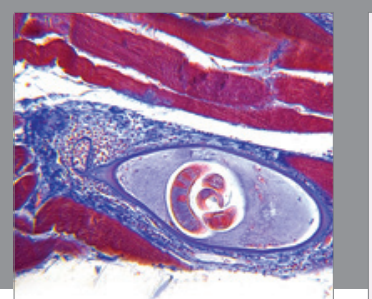

Gastroenterology Research and Practice

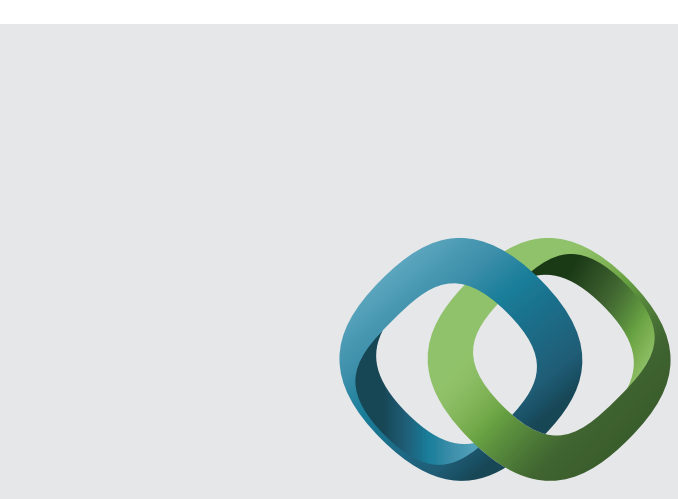

\section{Hindawi}

Submit your manuscripts at

http://www.hindawi.com
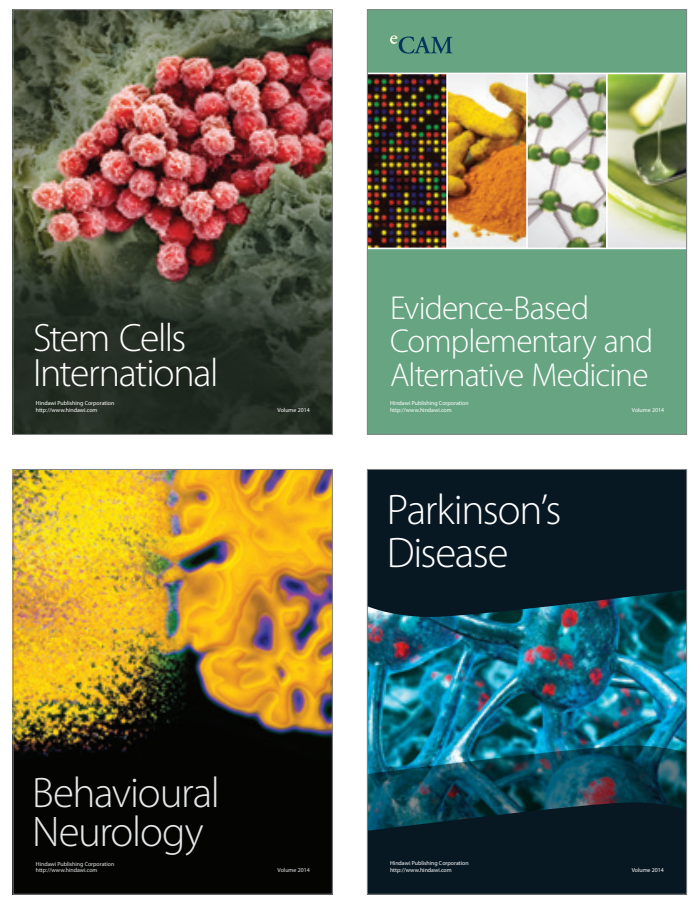
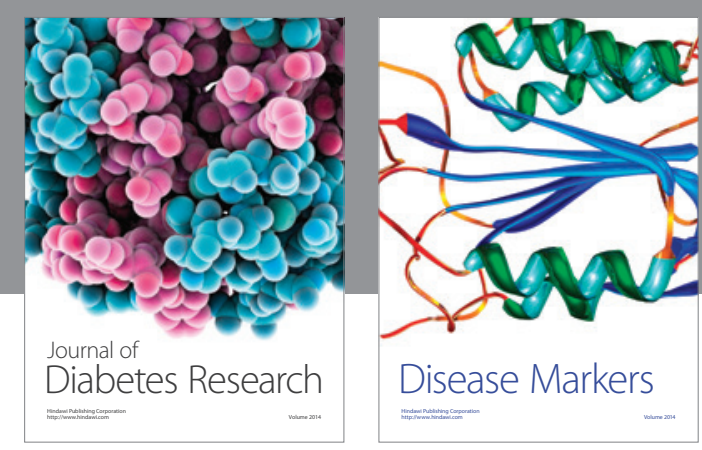

Disease Markers
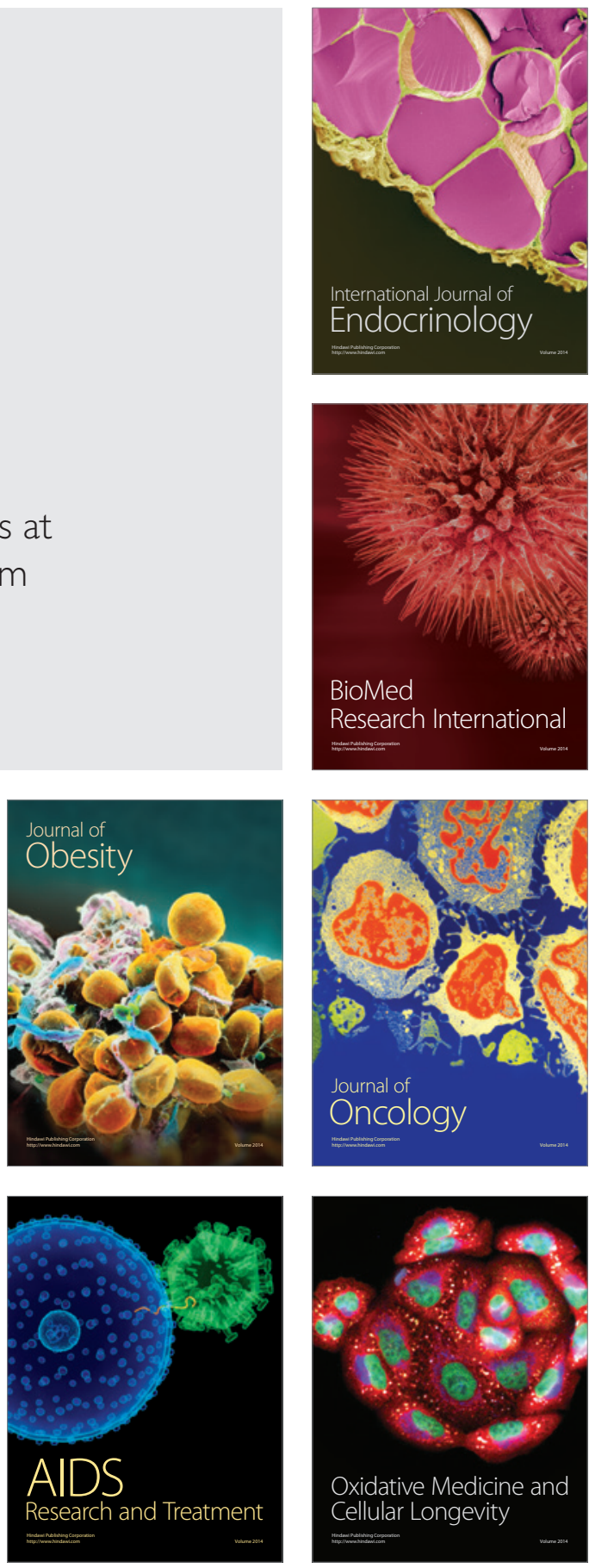